\title{
Practical theologians' calling to serve in the field of gerontology
}

\begin{tabular}{|c|c|}
\hline \multicolumn{2}{|c|}{ Petria M. Theron ${ }^{1}$} \\
\hline \multicolumn{2}{|c|}{$\begin{array}{l}\text { Affiliation: } \\
{ }^{1} \text { Faculty of Theology, } \\
\text { North-West University, } \\
\text { Potchefstroom Campus, } \\
\text { South Africa }\end{array}$} \\
\hline \multicolumn{2}{|c|}{$\begin{array}{l}\text { Note: } \\
\text { This article was initially } \\
\text { a paper delivered at the } \\
\text { annual meeting of the } \\
\text { Society for Practical Theology } \\
\text { in Potchefstroom, 23-25 } \\
\text { January 2013. The theme } \\
\text { of the conference was } \\
\text { 'Practical theology and } \\
\text { service delivery'. This article } \\
\text { is published in the Section } \\
\text { Practical Theology of the } \\
\text { Society for Practical Theology } \\
\text { in South Africa. }\end{array}$} \\
\hline \multicolumn{2}{|c|}{$\begin{array}{l}\text { Correspondence to: } \\
\text { Petria Theron }\end{array}$} \\
\hline \multicolumn{2}{|c|}{$\begin{array}{l}\text { Email: } \\
\text { petria.theron@nwu.ac.za }\end{array}$} \\
\hline \multicolumn{2}{|c|}{$\begin{array}{l}\text { Postal address: } \\
\text { Private Bag X6001, } \\
\text { Potchefstroom 2520, } \\
\text { South Africa }\end{array}$} \\
\hline \multicolumn{2}{|c|}{$\begin{array}{l}\text { Received: } 14 \text { Feb. } 2013 \\
\text { Accepted: } 31 \text { May } 2013 \\
\text { Published: } 12 \text { Aug. } 2013\end{array}$} \\
\hline \multicolumn{2}{|c|}{$\begin{array}{l}\text { How to cite this article: } \\
\text { Theron, P.M., 2013, Practical } \\
\text { theologians' calling to serve } \\
\text { in the field of gerontology', } \\
\text { HTS Teologiese Studies/ } \\
\text { Theological Studies 69(2), } \\
\text { Art. \#1942, } 7 \text { pages. http:// } \\
\text { dx.doi.org/10.4102/hts. } \\
\text { v69i2.1942 }\end{array}$} \\
\hline $\begin{array}{l}\text { Copyright: } \\
\text { (C) 2013. The } \\
\text { Licensee: AOS } \\
\text { OpenJournals } \\
\text { is licensed un } \\
\text { Creative Com } \\
\text { Attribution Li }\end{array}$ & $\begin{array}{l}\text { IS } \\
\text { IS } \\
\text { This work } \\
\text { der the } \\
\text { nons } \\
\text { ense. }\end{array}$ \\
\hline Read online: & \\
\hline 口itga & $\begin{array}{l}\text { Scan this QR } \\
\text { code with your } \\
\text { smart phone or } \\
\text { mobile device } \\
\text { to read online. }\end{array}$ \\
\hline
\end{tabular}

The South African demographic statistics echo the global trend of an ageing population. This fact poses challenges to the country's labour supply, to health care, retirement and intergenerational relations. The elderly are faced with specific challenges such as negative views regarding older people, discrimination and prejudice based on age, changing roles, the loss of a support system when children emigrate, financial problems, abuse and neglect, emotions of fear and depression, and the struggle to find meaning in life and suffering. The field of study that concerns ageing and older adulthood is called gerontology. Joan Erber defines it as 'the study of the biological, behavioural, and social phenomena that occur from the point of maturity to old age.' It is an interdisciplinary field where different disciplines seek to address the problems associated with ageing. Biologists focus on the biological processes of ageing, psychologists focus on aspects like mental abilities, personality and behaviour, whilst sociologists study the social roles, group behaviour and status of older people. The question may be asked what is being done regarding the spiritual and emotional needs of the elderly. This is the niche of practical theology, as indicated by one definition of practical theology that it is 'a place where religious belief, tradition and practice meet contemporary experiences, questions and actions and conducts a dialogue that is mutually enriching, intellectually critical, and practically transforming' according to Pattison and Woodward. The aims of this exploratory article are (1) to investigate to what extent research in practical theology has addressed the spiritual and emotional needs of the elderly and (2) to identify opportunities where practical theology may provide service in the field of gerontology.

\section{Introduction}

The population of the world is getting older. According to a report in Business Day (27 August 2008:11), the number of working Europeans per retiree will drop by half by 2060. The ageing population will put extra pressure on European governments, as a smaller number of people have to support a growing number of retired people. The 2010 census in China revealed the same trend, namely, on the one hand a decrease in the population growth rate and on the other hand the ageing population. Between 1990 and 2000, the Chinese population increased by $11.7 \%$, but between 2000 and 2010, the growth was only 5.84\%. The census also showed that the population was experiencing an accelerated ageing trend. During the 2000 census, $10.33 \%$ of the population was 60 or older, but in 2010, the percentage increased to $13.26 \%$. As in Europe, these facts have far-reaching consequences for the world's second biggest economy, as the number of potential workers, those who must look after the greying population, is decreasing (Buckley \& Martina 2011:18). The ageing of the population is also a reality in Africa. The African Development Bank reported that in 2000, 3.3\% of the African population was over 65, but this has risen to $3.6 \%$ in 2011. The bank estimates that by 2030 , it will be $4.5 \%$ and by 2050 , the elderly will comprise almost $10 \%$ of the population in Africa. African nations are not well equipped to deal with the growing number of older people (Delonno 2011:18).

The South African demographic statistics echo the global trend of an ageing population. In 1996 people of 65 and older comprised $4.767 \%$ of the population, but in 2011 the percentage went up to 5.019\% (Statistics SA 2001:20; Statistics SA 2011:9). The ageing population not only poses challenges to the country's labour supply and the productivity of the workforce, but also to health care, retirement, living arrangements and intergenerational relations. The challenge is to enable people to age with dignity and financial security (Business Day 18 January 2012:5; Lekota 2012:5).

In April 2002, 159 governments, including South Africa, adopted the Madrid International Plan of Action on Ageing (MIPAA) at the Second World Assembly on Ageing. They identified the key challenge as 'building a society for all ages' and focused on three main areas: older persons and development; advancing health and well-being into old age; and ensuring enabling and supportive environments with the aim to reorient the ways in which their societies perceive, 
interact with and care for their older citizens (United Nations 2002). The Older Persons Act no. 13 of 2006 was published to alleviate the plight of older South African citizens by setting up a framework for their empowerment and protection. The Act promotes and maintains the rights, status, wellbeing, and safety and security of older persons (South African Government 2006).

In his foreword, Kofi Annan, the Secretary-General of the UN at that stage, states that each and every one of us, young and old, has a role to play in promoting solidarity between generations, in combating discrimination against older people, and in building a future of security, opportunity and dignity for people of all ages (United Nations 2002).

It is evident that the advanced age group of the population should receive more attention. The field of study that deals with ageing and older adulthood is called gerontology (Segal, Qualls \& Smyer 2011:4, 17). Gerontology is defined by Erber (2010:394) as the study of the biological, behavioural, and social phenomena that occur from the point of maturity to old age.' Aiken (1995:21) mentions that gerontology is an interdisciplinary field where different disciplines are seeking to address the problems associated with ageing. Biologists focus on the biological processes of ageing, psychologists focus on aspects like mental abilities, personality and behaviour, whilst sociologists study the social roles, group behaviour and status of older people. The focus is not only on research, but also on the improvement of the health and wellbeing of older people. The question may be asked what is being done regarding the emotional and spiritual needs of the elderly. That the answer to this question points to the niche of practical theology is not surprising, considering MillerMcLemore (2012:5) reference to practical theology 'as an activity of believers seeking to sustain a life of reflective faith in the everyday.' Forrester (2010:143) makes it even clearer when he states that 'practical theology is the theological discipline which is primarily concerned with the interaction of belief and behaviour.' He qualifies his statement by saying that practical theology is about critical theological reflection on the praxis. This corresponds with the definition given by Pattison and Woodward (2005:7), namely:

practical theology is a place where religious belief, tradition and practice meet contemporary experiences, questions and actions and conducts a dialogue that is mutually enriching, intellectually critical, and practically transforming. (p. 7)

From the above-mentioned statistics regarding a greying population and the definitions of gerontology and practical theology, it is clear that the field of gerontology also needs to be addressed from a practical-theological perspective.

The central theoretical argument of this article is that practical theologians have a responsibility and a calling to provide service in the field of gerontology. In this exploratory article I will first give an overview of research done since 2000 by South African practical theologians in order to investigate their contribution to the field of gerontology. Then I will examine recent developments in practical theology in order to establish what practical theologians' task is, including the task in the field of gerontology. I will conclude this article by identifying opportunities where practical theologians may be of service in addressing the needs of the elderly.

\section{Recent practical-theological research in gerontology}

Although there are practical theologians in other parts of the world who have done extensive research in the field of gerontology, like the influential Ruard Ganzevoort ${ }^{1}$ of the Netherlands, the focus in this article is to evaluate the contribution of South African practical theologians. I will investigate the current state of research in the field of gerontology from a practical-theological perspective. I will explore the content of applicable dissertations, theses and articles published since 2000 .

\section{Dissertations and theses}

I used the databases of NEXUS, ProQuest and SACat and found only three completed studies with titles related to gerontology:

- De Wet, R., 2010, 'Pastorale terapie aan die persoon bo tagtig jaar', PhD proefskrif, Universiteit van die Vrystaat.

- De Jager, P.J.C., 2008, 'Pastorale berading aan bejaardes na trauma van die onnatuurlike dood van 'n volwasse kind', PhD proefskrif, Noordwes Universiteit.

- Brunsdon, A.R., 2006, 'Pastoraat aan die afgetrede egpaar deur kanker geaffekteer: 'n Narratiewe benadering', PhD proefskrif, Universiteit van die Vrystaat.

Evaluating the titles of these three studies, the focus area of each study clearly comes to the fore. Two studies address particular groups amongst the elderly, namely the group that is affected by cancer and the group that lost an adult child through unnatural death. It seems as if only one study, that of De Wet, addresses general gerontological issues from a practical-theological perspective. In the following paragraphs, I will briefly analyse the content of each of the studies in order to evaluate its contribution to the field of gerontology.

\section{De Wet (2010)}

In his thesis, 'Pastoral therapy to the person older than 80 years', De Wet focuses on the pastoral-therapeutic implications of the growing number of older persons in the population. Progressive developments in medical research and treatment as well as socio-economic change offer people a longer life expectancy and enable them to remain active for a longer period. The population group showing the largest proportional increase is the age group above 80 , but this group also includes the largest number of frail persons, who are in special need of pastoral therapeutic support and involvement in order to ensure spiritual and emotional well-being. It is of utmost importance that they will be treated with respect and human dignity and that they feel

1.All his articles are listed on his website (http://www.ruardganzevoort.nl). One article of particular interest is titled 'Minding the wisdom of ages: Narrative approaches in pastoral care for the elderly', Practical Theology 3(3), 331-340. 
they are understood and appreciated. As the elderly grow in their awareness that life is finite, they also are in need of deeper spiritual experiences and of having hope and finding meaning in life and in suffering.

In his study the author addresses the pastoral implications of aspects like different retirement theories (Disengagement, Activity and Continuity), gains and losses associated with ageing, different stages in ageing and the different tasks and challenges associated with each stage. He also gives attention to pastoral counselling to the person with dementia and Alzheimer's disease in particular. De Wet stresses the point that pastoral counselling may significantly enhance the quality of life of the elderly. This is said against the background that the elderly do not have unlimited time available for counselling, as they face factors that may impede meaningful communication, such as the loss of hearing, sight, mobility and clarity of mind. De Wet concludes that pastoraltherapeutic conversations give the elderly the opportunity to tell their stories, and by telling their stories, they gain courage for life. They may also gain new perspectives that make life worthwhile and may even lead them to finding answers to questions of the past, and to acceptance.

The study of De Wet provides valuable gerontological insights from a practical-theological perspective into the life of the person older than 80 years of age. He draws attention to the importance of pastoral involvement with the elderly in order to ensure their spiritual and emotional well-being, especially as they have a growing need for deeper spiritual experiences. Issues that need to be addressed are hope, the meaning of life and the meaning of suffering, to name just a few. I agree with De Wet that pastoral counselling to the elderly is indispensable and that it may enhance the quality of their lives significantly, as it will result in them feeling understood and appreciated.

\section{De Jager (2008)}

This study deals with the pastoral counselling of elderly parents who lost their mature child due to unnatural death. This traumatic event leaves the parents, who are already experiencing other losses because of ageing, with a significant unexpected void. The child is not 'supposed' to die before the parents and the one who was 'supposed' to provide support to the ageing parents is gone. The elderly parents may experience an existential conflict, because they are burying their 'future' with their child. Furthermore, they often do not receive the necessary support, as all the attention is focussed on the mourning spouse and children of the deceased.

Despite the fact that De Jager offers a useful model to pastoral counsellors in counselling elderly parents after the unnatural death of a mature child, the applicability of the study is limited to the emotional and spiritual needs of this specific group amongst the elderly.

\section{Brunsdon (2006)}

The focus of Brunsdon, in his study 'Pastoral therapy to the retired couple affected by cancer: A narrative approach', is on the effect that diagnosis of cancer has on the retired couple and how it can be countered by a narrative approach in counselling. It is shattering news for a retired couple to be confronted by a diagnosis of cancer, because it entails suffering and puts the so-called golden years in jeopardy, including the positive opportunities associated with this unique life-stage. The narrative approach gives the couple the opportunity to tell their problem-saturated story in a reflective manner. In doing so, the negative discourses of cancer can be heard and the couple has the opportunity to be reminded that a full life is possible in spite of a serious illness. The narrative approach is a valuable model for counselling as it can help the couple to lead a meaningful life amidst an existential crisis.

Even though Brunsdon's study is valuable for counselling the elderly who are affected by cancer, it does not address the experiences and needs of the elderly in general.

\section{Published articles}

By studying the content of peer-reviewed scientific articles, one gets an idea of the amount of research that is being done by practical theologians in the field of gerontology. Eight South African scientific journals that publish articles from a practical-theological perspective were identified. I used the SA ePublications database to access all the articles in journals that are available online. The following journals were included in the search:

- Acta Theologica - Volume 21, Issue 1, 2001 to Volume 32, Issue 1, 2012; including Supplementum 2 to 15 (34 publications in total)

- HTS Teologiese Studies/Theological Studies - Volume 58, Issue 1, 2002 to Volume 68, Issue 2, 2012; including Supplementum 9 (35 publications in total)

- In die Skriflig/In Luce Verbi - Volume 35, Issue 1, 2001 to Volume 46, Issue 1, 2012; including Supplementum 3 (44 publications in total)

- Journal for Christian Scholarship - Volume 39, Issue 3 \& 4, 2003 to Volume 48, Issue 1 \& 2, 2012; including Special edition 1 \& 2 and Special issue 1 (24 publications in total)

- Koers: Bulletin for Christian Scholarship - Volume 66, Issue 1 \& 2, 2001 to Volume 76, Issue 3, 2011 (38 publications in total)

- Dutch Reformed Theological Journal (NGTT) - Volume 43, Issue 1 \& 2, 2002 to Volume 53, Issue 1 \& 2, 2012; including Supplementum 2004, 2010, 2011 (24 publications in total)

- Practical Theology in South Africa - Volume 17, Issue 2, 2002 to Volume 24, Issue 2, 2009; including Special edition 3 (18 publications in total)

- Verbum et Ecclesia - Volume 23, Issue 1, 2002 to Volume 33, Issue 1, 2012; including Special issue 2 (25 publications in total).

Each of the 242 publications has several articles. Amongst the vast body of articles, I found only five articles with titles related to the field of gerontology:

- De Beer, E.J., 2011, "n Teologies-etiese beoordeling van aftrede', In die Skriflig/In Luce Verbi 45(4), 803-823.

- Malan, E. \& Dreyer, Y.,2009, 'Multidissiplinêre beskouinge op veroudering vanuit 'n pastorale perspektief', HTS Teologiese Studies/Theological Studies 65(1), 200-208. 
- Brunsdon, A.R. \& Lotter, G.A., 2008, 'Aftrede as integrasionele taak', Koers 73(2), 283-302.

- De Klerk, B.J., 2005, "n Liturgie van aftrede', In die Skriflig/ In Luce Verbi 39(3), 463-485.

- Louw, D.J., 2005, 'Geloofsvolwassenheid en Christelike spiritualiteit binne die knyptang van prestasiedruk tydens vroegbejaardheid', In die Skriflig/In Luce Verbi 39(3), 423-439.

It was quite a revelation to discover that only five articles have been published since 2000 addressing issues pertaining to people in the group maturity to old age. By looking at the titles of the articles, the following becomes immediately apparent. One article addresses the performance pressure that people between 50 and 65 years experience. Traditionally, this group does not yet 'qualify' to be included in the group of the elderly. Three articles focus on issues regarding retirement. Only one article, the article of Malan and Dreyer, specifically addresses the topic of ageing. I will now make an analysis of the content of these five practical-theological articles in order to determine their contribution to gerontology.

\section{De Beer (2011)}

De Beer, in his article 'A theological-ethical judgement of retirement', focuses on the fact that people are forced to retire at a certain age. He argues that in light of the fact that populations are growing older and more people are experiencing financial problems because of the world's dire economic situation, people should, from a theologicalethical perspective, have the opportunity to be actively part of the workforce as long as it is physically possible. He explores biblical principles regarding work and retirement and, according to him, the most important principle is that human beings were created in God's image as 'ever-working beings'. People thus have the right to work as long as they are physically able to do so, in order to contribute meaningfully to society. If they are not given this opportunity, it may have a negative impact on their mental wellbeing.

The author addresses the theological-ethical aspects of retirement, but does not address the emotional and spiritual needs of the retiree.

\section{Malan and Dreyer (2009)}

In their article, 'Multiprofessional aspects of ageing seen from a pastoral perspective', Malan and Dreyer show how the social environment of the elderly changes because of retirement. The care of the elderly is more problematic because of urbanisation, emigration of children, lower government subsidy for old age homes, expensive retirement villages, higher life expectancy, insufficient funds for retirement and an ageing population. According to the authors, practical theology is the ideal discipline to take a leading role in the necessary multiprofessional conversation with gerontology. The lack of funds and workers are the cause that the elderly do not receive sufficient social and spiritual care. The result is that aspects like abuse and neglect are on the increase. Pastors often feel that they are not sufficiently equipped to handle the material, psychosocial and religious needs of the elderly. Aspects that need to be addressed are preparation for retirement; financial security; loneliness; discrimination based on age; changing roles, rights and responsibilities; loss of support systems when children emigrate; emotions like fear, depression and worry; loss of self-worth and lack of finding meaning in life and suffering. Networks for community-based care for the aged are necessary. Faith communities have a responsibility and should play a role to equip these support systems and to develop service centres for the aged, so that the elderly can stay longer in their own homes. Security networks need to be developed to improve safety for the elderly at home.

Malan and Dreyer consult other disciplines to learn from them. They discuss the activity theory of Neugarten, Havighurst and Tobin. According to this theory, older people age better when they stay active. However, activity is more than just keeping people busy; it is about relationships and involvement in the community. It improves the self-concept of people and increases life fulfilment. Although activity is important, people have a natural tendency to withdraw from society, because factors like retirement, loss of income, health problems, loss of one's partner through death, lower prestige and changing roles in the family contribute to withdrawal. The authors argue that the faith community has an important role to organise activities to counter social isolation. They also believe that personality theories, withdrawal theories and continuity theories may assist in understanding ageing. The SOC-theory (selectivity, optimisation, compensation) is also valuable to enhance adaptation to ageing. Malan and Dreyer conclude that the elderly are in need of pastoral care and that pastoral counsellors need to be equipped not only to counsel the elderly, but also to support family members and caregivers.

The authors deal extensively with the topic of gerontology and the needs of the elderly from a practical-theological perspective. I agree with their conclusion that the elderly are in need of pastoral care and that pastoral counsellors need to be equipped not only to counsel the elderly, but also to support family members and caregivers. According to the authors, it is clear that caring for the elderly is still a big challenge to the church and a fallow field for practical theology.

\section{Brunsdon and Lotter (2008)}

The focus of the article 'Retirement as integrational task' is on the narrative approach to guide retirees to integrate life and faith in such a manner that they discover meaning and experience fulfilment. Instead of seeing retirement in the traditional way as disengagement, a stage associated with feelings of futility, it may be viewed as an active, productive time of life in which new life opportunities can be explored. According to Brunsdon and Lotter, the narrative approach can be an effective tool to assist the elderly to experience meaning in the final stage of life and to live optimally by integrating God's Story with their own stories that may 
well be filled with disappointment, fear and insecurity. This integration will give rise to a new story filled with hope and meaning for the future. The authors show how the book of Ecclesiastes may help retirees to think about the meaning of life. Life becomes meaningful through helping relationships with others and in relationship with God. The authors focus on the phenomenon of retirement and present it as a complex phase with unique challenges. For many, their work is an extension of their personality and when they are 'forced' to retire, they experience a sense of uselessness. Retirees often struggle to survive financially because of the economic climate and the higher life expectancy. Retirees go through different phases: honeymoon, experience of loss, a search for meaning, and depression. They need help to find meaning and fulfilment.

This article focuses on the concepts of retirement and narrative therapy. The attention of the authors is thus focussed on a specific group, namely the retirees and their specific spiritual and emotional needs.

\section{De Klerk (2005)}

Retirement is a time of huge changes and entails a process consisting of several phases. The first few weeks after retirement are, what is called, the honeymoon phase. It is followed by a time of experiencing loss, a time of searching for meaning and even a time of depression. People need meaningful relationships and need to be involved in some work, even if it is voluntary work. Retirees need to be intellectually active and need to form new support systems. In his article 'A liturgy of retirement', De Klerk states that the sociological, financial and psychological aspects of retirement often receive attention in literature, but the religious side does not. He addresses this lacuna by proposing a 'liturgy of retirement', because a liturgy does not only refer to the Sunday service, but extends into daily life. The Sunday service equips people for their daily living, for their service to God in his kingdom, to be witnesses in the world and to live up to their calling. The article investigates the possibility of a liturgy of retirement, containing elements of wonder, humiliation, reconciliation, commitment and proclamation. Such a liturgy will help retirees to understand that in God's eyes who they are is more important than what they do. It will assist them to formulate spiritual objectives and to realise that religion is an important source of power. It will help them to be at peace with personal limitations and the fleetingness of life.

De Klerk's focus is also on retirement and addresses certain spiritual aspects that may assist the retiree to be at peace with retirement and the fleetingness of life. He proposes a liturgy of retirement.

\section{Louw (2005)}

Louw's focus in his article with the title, 'Spiritual maturity and Christian spirituality within the crush between performance pressure and adjustment to early pre-elderliness', is on people in the 'in-between stage'. He refers to people between
50 and 65 years of age who are caught up in the pressure of, on the one hand, performing in their career and, on the other hand, preparing for retirement. Their preparation for retirement should include aspects such as coming to terms with health issues, possible decline in intellectual abilities, loss of control, dependency and financial insecurity. It is in this phase that people are acutely aware of their vulnerability and want to come to terms with paradoxical issues in their lives and to be at peace with their faith, so that they can have an integrated vision for life. People want to find meaning in life, also in suffering. They need to develop an eschatological life-view filled with hope. Louw proposes that the New Testament concept of parrhēsia (perseverance, courage, persistence) can provide people with steadfastness, continuity and direction for the future. It can give them stamina and courage to continue in faith and to endure the pressure of this 'in-between stage'. Parrhēsia replaces fear with trust and confidence.

In this article, Louw focuses more on issues associated with the pre-elderly phase than the elderly phase; thus, his contribution to gerontology is limited.

\section{Summary of current practical-theological research in gerontology}

From the above investigation into the current state of research by practical theologians, it is evident that little research has been done in the field of gerontology. I found only one thesis and one article that address general gerontological issues from a practical-theological perspective. Retirement has received more attention and certain issues concerning ageing and the elderly have been identified, but much more should be done, because De Wet is correct when he speaks about the importance of pastoral counselling to the elderly to ensure their spiritual and emotional well-being. Malan and Dreyer (2009) are correct in their assessment that caring for the elderly is still a big challenge to the church and an uncultivated field for practical theology. They argued that practical theology should take the lead in the multiprofessional conversation with gerontology. It is thus necessary to focus on practical theology in order to ascertain its role and responsibility in the field of gerontology.

\section{Practical theology's role and responsibility in the field of gerontology}

In his book Practical Theology: An introduction, Richard Osmer (2008:ix-x) refers to the 'period of creative ferment' of practical theology during recent decades. It is indeed clear from the recent past that a significant break from the older practical theology models has been made. Practical theology is no longer a field exclusively concerned with the application of helpful techniques and skills in the life of the church; nor is it merely concerned with the tasks of the clergy or the life of congregations. Today practical theology is involved in matters of public importance and it is often directed towards 
the shaping of public policy and social transformation. The scope of practical theology thus not only comprises the church, but also encompasses the web of life and is directed towards the common good.

According to Osmer (2011:2), contemporary practical theology is influenced by a paradigm of reflective practice. He refers to it as 'reflective' in relation to four tasks that he has identified in the pastoral practice. These four tasks function according to a hermeneutical circle or spiral. He associates each task with a question to guide the process and describes the tasks as follows:

- Descriptive-empirical: What is going on? Gathering information to understand particular episodes, situations or contexts better.

- Interpretive: Why is this going on? Entering into a dialogue with the social sciences to interpret and explain why certain actions and patterns are taking place.

- Normative: What ought to be going on? Raising normative questions from the perspectives of theology, ethics and other fields.

- Pragmatic: How might we respond? Forming an action plan and undertaking specific responses that seek to shape the episode, situation or context in desirable directions.

Instead of simply following traditions and practices of the past, Christian leaders are enabled by the reflective practice paradigm to develop new forms of Christian practice in order to address the ever-changing challenges of the postChristendom, postmodern and globalising world in which we live. To Osmer (2011:5), practical theology is faced by the challenge to ground its identity and purpose in the mission of the church and to stay committed to the common good. Practical theology has a commitment to both the church and the world. The mission of the church cannot be separated from the missio Dei [the mission of God] that is essentially universal in scope. It is through listening, learning, speaking and sharing that practical theology can contribute to the common good of the world. Steyn and Masango (2011:1-2) agree that practical theology needs to be practical and be able to offer help to people who are in need of pastoral care, not only to people in the church, but also to people outside the church. The authors quote Browning, who said that practical theology should apply Christian practice to illuminate life's concrete problems and issues. They also quote Campbell, who argued that practical theology is concerned with the well-being of people in communities.

From the discussion regarding the task and responsibility of practical theology, it should be clear that the worldwide problem of an ageing population falls within the scope of matters of public importance and challenges posed by the postmodern and globalising world in which we live. Practical theology has a responsibility to serve the elderly, to address and to alleviate their spiritual and emotional needs and fears. Practical theologians have already identified certain gerontological issues, but a quick glance at related disciplines reveals more aspects regarding the needs of the elderly. These should also be addressed from a practical-theological perspective.

\section{Opportunities to practical theology of serving the elderly}

In the limited research practical theologians have done in the field of gerontology, they have identified the following areas where practical theology may serve the elderly:

- discrimination and prejudice based on age

- the effect of changing roles

- the loss of a support system when children emigrate

- financial insecurity

- abuse and neglect

- emotions of fear and depression

- social isolation due to retirement, loss of income, health problems, death of a partner, lower prestige and changing roles in the family

- loss of self-worth and the struggle to find meaning in life and in suffering

- the growing need of the elderly for a deeper spiritual life and having hope for the future

- retirement preparation, including health issues, decline in intellectual abilities, loss of control, dependency, and the need to experience retirement as a time of meaning, fulfilment and new opportunities

- caring for the elderly becoming more problematic because of urbanisation, lower or no government subsidy for old age homes, expensive retirement villages, higher life expectancy, deterioration in the security situation of the country, and an ageing population

- the elderly not receiving sufficient social and spiritual care because of lack of funds and workers

- pastors often feeling that they are not sufficiently equipped to handle the material, psychosocial and religious needs of the elderly

- faith communities needing to equip pastoral counsellors to counsel the elderly, to support family members and to support care givers

- faith communities needing to develop service centres for the aged so that they can stay in their own homes longer.

Related disciplines reveal added gerontological aspects that offer opportunities to practical theologians to serve the elderly. Amongst others, I want to mention the following:

- dealing with grief (Aiken 1995:390-397; Erber 2010:367373)

- dealing with frailty (Louw 2008:495-497)

- the reality of death (Aiken 1995:370-371, 377; Erber 2010:365-366)

- the search for new identity in old age (Aiken 1995:161)

- the marital relationship and the occurrence of divorce (Erber 2010:274, 375-376)

- sexuality (Louw 2008:513)

- relationships with children and grandchildren, including unresolved interpersonal conflicts (Aiken 1995:249, 378) 
- relationship with siblings (Erber 2010:285)

- friendships (Erber 2010:287-288)

- successful ageing (Louw 2008:499-502)

- the importance of religion and religious beliefs (Aiken 1995:328-329, 372)

- coming to terms with life as it has been lived (Coleman 1995:69)

- making sense of a changing society (Coleman 1995:69)

- self-esteem (Erber 2010:252)

- personal control (Erber 2010:255-257).

When Malan and Dreyer (2009) speak about the need not only to equip pastoral counsellors for their task to counsel the elderly, but also to support family members and care givers, I see the need to develop programmes to serve this purpose. To be effective, these programmes will have to incorporate inter alia the above-mentioned aspects. It is my conviction that practical theology is the ideal discipline to fulfil this need.

\section{Conclusion}

Despite the fact that the world's population is growing older, the spiritual and emotional well-being of the elderly are not attended to sufficiently. By definition, practical theology is ideally situated to take the lead in the multiprofessional conversation with gerontology in order to fulfil this need. An investigation into recent research revealed that gerontology is still an uncultivated field for practical theology. Aspects like grief, frailty, death, search for new identity in old age, marital relationships, divorce, sexuality, relationships with children, grandchildren and siblings, unresolved interpersonal conflicts, friendships, and the importance of religion and religious beliefs need to be addressed from a practical-theological perspective. It is necessary to develop programmes to equip pastoral counsellors for their task to counsel the elderly and to support their family members and caregivers. Gerontology offers many opportunities to practical theology to serve the growing portion of the world's population - the elderly.

\section{Acknowledgements Competing interests}

The author declares that she has no financial or personal relationship(s) that may have inappropriately influenced her in writing this article.

\section{References}

'Ageing population to challenge EU', Business Day, 27 August, 2008, p. 11.

Aiken, L.R., 1995, Aging: An introduction to gerontology, Sage, Thousand Oaks, CA.

Brunsdon, A.R., 2006, 'Pastoraat aan die afgetrede egpaar deur kanker geaffekteer: 'n Narratiewe benadering', PhD proefskrif, Universiteit van die Vrystaat.

Brunsdon, A.R. \& Lotter, G.A., 2008, 'Aftrede as integrasionele taak', Koers 73(2), 283302. http://dx.doi.org/10.4102/koers.v73i2.163

Buckley, C. \& Martina, M., 2011, 'China is fast urbanising and becoming older, census shows', Star, 29 April, p. 18.

Coleman, P.G., 1995, 'Facing the challenges of aging: Development, coping, and meaning in life', in J.F. Nussbaum \& J. Coupland (eds.), Handbook of communication and aging research, pp. 39-74, L. Erlbaum Associates, Mahwah, NJ.

De Beer, E.J., 2011, "n Teologies-etiese beoordeling van aftrede', In die Skriflig/In Luce Verbi 45(4), 803-823. http://dx.doi.org/10.4102/ids.v45i4.203

De Jager, P.J.C., 2008, 'Pastorale berading aan bejaardes na trauma van die onnatuurlike dood van 'n volwasse kind', PhD proefskrif, Noordwes Universiteit.

De Klerk, B.J., 2005, "n Liturgie van aftrede', In die Skriflig/In Luce Verbi 39(3), 463485. http://dx.doi.org/10.4102/ids.v39i3.398

Delonno, P., 2011, 'Africa joins world with ageing population boom', Star, 18 November, p. 18.

De Wet, R., 2010, 'Pastorale terapie aan die persoon bo tagtig jaar', PhD proefskrif, Universiteit van die Vrystaat.

Erber, J.T., 2010, Aging and older adulthood, 2nd edn., Wiley-Blackwell, Chichester.

Forrester, D.B., 2010, Forrester on Christian Ethics and Practical Theology: Collected writings on Christianity, India and the social order, Ashgate, Farnham.

Lekota, I., 2012, 'Rise of "greying generation"', Sowetan, 02 October, p. 5.

Louw, D.J., 2005, 'Geloofsvolwassenheid en Christelike spiritualiteit binne die knyptang van prestasiedruk tydens vroegbejaardheid', In die Skriflig/In Luce Verbi 39(3), 423-439. http://dx.doi.org/10.4102/ids.v39i3.396

Louw, D.J., 2008, Cura vitae: Illness and the healing of life in pastoral care and counselling, Lux Verbi, Wellington.

Malan, E. \& Dreyer, Y., 2009, 'Multidissiplinêre beskouinge op veroudering vanuit ' $n$ pastorale perspektief', HTS Teologiese Studies/Theological Studies 65(1), 200208. http://dx.doi.org/10.4102/hts.v65i1.182

Miller-McLemore, B.J., 2012, 'The contributions of Practical Theology', in B.J. MillerMcLemore (ed.), The Wiley-Blackwell companion to Practical Theology, pp. 1-20, Wiley-Blackwell, Chichester.

Osmer, R.R., 2008, Practical theology: An introduction, Eerdmans, Grand Rapids, MI.

Osmer, R.R., 2011, 'Practical theology: A current international perspective', HTS Teologiese Studies/Theological Studies 67(2), \#Art. 1058, 7 pages. http://dx.doi. org/10.4102/hts.v67i2.1058

Pattison, S. \& Woodward, J., 2000, A reader in Practical Theology, Blackwell, Oxford.

Pattison, S. \& Woodward, J., 2005, 'An introduction to pastoral and practical theology', in J. Woodward \& S. Pattison (eds.), The Blackwell reader in pastoral and practical theology, pp. 1-19, Blackwell Publishing, Malden.

Segal, D.L., Qualls, S.H. \& Smyer, M.A., 2011, Aging and mental health, 2nd edn., Wiley-Blackwell, Chichester.

South African Government, 2006, 'Older persons Act no. 13', Government Gazette 497(2), 2.

Steyn, T.H. \& Masango, M.J., 2011, 'The theology and praxis of practical theology in the context of the Faculty of Theology', HTS Teologiese Studies/Theological Studies 67(2), Art. \#956, 7 pages. http://dx.doi.org/10.4102/hts.v67i2.956

Statistics South Africa, 2001, Primary tables South Africa: Census '96 and 2001 compared, viewed 18 October 2012, from http://www.statssa.gov.za/census01/ html/RSAPrimary.pdf

Statistics South Africa, 2011, Mid-year population estimates: 2011, viewed 18 October 2012, from http://www.statssa.gov.za/publications/P0302/P03022011.pdf

'The challenge of an older SA', Business Day, 18 January, 2012, p. 5.

United Nations, 2002, Political declaration and Madrid international plan of action on ageing, viewed 16 May 2013, from http://social.un.org/index/Ageing/Resources/ MadridInternational PlanofActiononAgeing.aspx 